\title{
Ecological surveys of certain plant communities around urban areas of Karachi
}

\section{MUHAMMAD, ZAFAR IQBAL; SHAH, S. Z.; SHAFIQ, M.}

\author{
Department of Botany, University of Karachi,Karachi- 75270, Pakistan \\ EmailAdd:shafiqeco@yahoo.com.shafiq_ecopk@hotmail.com
}

\begin{abstract}
A phytosociological study was conducted as an initial assessment of the vegetation on different sites to determine the community structure and how the communities were related based on their species composition and edaphic characteristics. The communities were distinct types ranging from halophytes to xerophytes with disturbed in nature. Plant communities based on first leading dominant species (Prosopis, Avicennia, Gynandropis, Salvadora, Ipomea, Halopyrum, Limonium, Abutilon and Calotropis) were explored in the study area. Out of thirtynine plant species, Prosopis juliflora attained the highest total importance value index (I.V.I.) followed by Avicennia marina, Suaeda fruticosa and Gynandropsis gynandra. Nine species attained first leading position. Thirteen species attained second dominant position. However, twelve species attained third dominant position in all stands. P. juliflora was the only species that was found six times as a first dominant, three times as second and one time as a third dominates species. None of the other species was in a position to get first, second and third position as a leading dominant in all stands. The communities were of heterogeneous type, with low species diversity and ranged from 1.36 to 4.54. Most of the plant communities showed less than 50\% CMI values. However, Prosopis in association with Pasplidium and Cenchrus community showed highest CMI value (70.00). The soils of the study areas were sandy loam, loamy sand, loamy silt, sandy and silty. The soils are alkaline in nature. An appreciable amount of calcium carbonate (13-26\%) with moderate percentage of maximum water holding capacity (19-41\%) and high soil EC $(593 \mathrm{~s} / \mathrm{cm} \mu)$ were recorded. It was also observed that certain edaphic and human activity, discharge of pollutants with out any pretreatment was found responsible for variation in the nature, structure and composition of vegetation. The plant growth and their continuity was in danger in many disturb areas, especially in some coastal areas where salinity and the incident of Tasman spirit oil spillage was occurred just few months before the survey carried out. Construction of flyover, expansion of the roads and cut down of the natural vegetation producing additional losses to flora of the region. @JASEM
\end{abstract}

The ecological surveys are necessary for an adequate characterization of a plant community. Disturbed areas considered those, where the integrity of the natural setting and natural system processes has been directly or indirectly affected by human activities. These activities could be for resource extraction, visitor use, development of maintenance, or invasion of nonnative sp. etc. The vegetation in the disturbed areas does not reflect a naturally evolved species composition, but rather a mixture of small remnant patches dominated by native plants patches of largely invasive weedy alien plants, and areas of mixed native and non native plants. All over the world, natural habitats are being degraded. There is evidence of contamination in the most remote parts of the world. The human population is getting larger, spreading and producing more complex and interactive disturbance on plant communities. There are few undisturbed habitats are left in some most part of the world. Nevertheless, there is also a general desire to maintain natural habitat for our enjoyment and for the continue well-being of nature. Plant ecologist have placed increasing emphasis on a gunctional understanding of vegetation (Lehsten and Kleyer, 2007). The response of plant communities to environmental change is often studied by analysing the composition of plant traits across communities. A lot of work has been done in ordinating the tropical, temperate, deciduous, desert and calcareous types of vegetation, whereas littler work has been reported from disturbed vegetation. The ecological survey of such disturbed areas conducted by few researchers, in order to know the damage done to ecology of the area and also to know the diversity and dispersion status of species in the area. In Pakistan some phytosociological studies on plant communities of different areas have been conducted (Akbar and Ahmed, 1991; Dasti and Agnew 1994; Iqbal, 1998). Arshad, et al., (2002) carried out a phytosociological assessment of natural reserve of national park Lalsuhanra and identified three distinct types of plant communities. Ahmed and Khattak, (2001) in quantitative studies on the vegetation of Islamabad concluded that due to large scale artificial addition the original vegetation is vanishing at certain places.

Khan et al., (1999) have described structure, composition and above ground standing phytomass for the summer aspect of some grass dominated communities of Karachi. In another studies, Khan and Shaukat (2005) have described above ground standing phytomass of some grass-dominated communities of Karachi for winter aspect. In past, few ecological studies have been made on the plant communities of different areas of Karachi (Shafiq, et al., 1992, Khan, 1993, Iqbal and Hussain, 1994; Iqbal and Shafiq, 1996, Iqbal, et al., 1998; Khan and Shaukat, 2005). Karachi is the biggest city of Pakistan. The city has more than 12 million population and ranked the $10^{\text {th }}$ amongst the biggest cities of the world. Increasing population pressure, expansion in industrial and residential areas, construction of roads, flyovers and invasion of nonnative species activities affected nature, structure and composition of the plant communities. Almost each and every area of the Karachi can be presented as the classical example of disturbance and pollution impact on plant 
communities. The city atmosphere is being affected badly by almost every type of environmental pollution. The natural vegetation of the region is either being replace by invasive species or is being removed by man for the construction of roads, flyover, building and industries. Dumping of domestic and industrial trash in Malir, Lyari and Hub rivers is also a common practice in the city, which has also affected the indigenous biodiversities of these wetlands. The aim of present investigation was to provide quantitative description of the vegetation on the disturbed areas of the Karachi city, which is changing from natural to semi-natural form due to anthropogenic disturbances, which are still in progress.

\section{MATERIALS AND METHODS}

\section{A: Description of the area}

The bioclimate of Karachi in the Holdridg's system falls in the category of "Tropical Bush Formation". The rainfall is irregular and average below $200 \mathrm{~mm}$ a year mostly in summer. The winter peak of precipitation is very low. Winter is the driest part of the year. Summer, which is very hot, the winter in this part of world is mild. Mean monthly minimum temperature for the month of January remains around $10^{\circ} \mathrm{C}-12.5^{\circ} \mathrm{C}$ due to the Siberian winds. The insulation is intense with global solar radiation varying from $3580 \mathrm{Kcal}^{-2} \mathrm{day}^{-1}$ for December to $5609 \mathrm{Kcal} \mathrm{M}^{-2}$ day $^{-1}$ for May. The diffused radiation is $20-30 \%$ of the global radiation (Ahmed et al., 1991) Rain in Karachi is seasonal, averaging less than $22 \mathrm{~cm}$ per year between June and September and rare for the remainder of the year. Occasionally, there are dry years too while strong coastal winds and better dew formation is the characteristic feature of Karachi.

\section{B: Vegetational survey}

A phytosociological survey of different habitats of Karachi was carried out in the months from July to October 2003 (Fig. 1). The study area is comprised of more than 30 square kilometer. Areas were sampled by Point centered quarter methods (Cottom and Curtis, 1956). Twenty sampling points were established at each venue with regular interval by spacing ten steps. Relative cover, relative frequency, and relative density were obtained. The importance value index (I.V.I.) for each species was obtained by addition of the above community attributes (Curtis and McIntosh, 1951). The community was named according to dominant species, which have highest I.V.I. Homogeneity of community was determined by Raunkiaers Law of frequency (1934). Community maturity index was found by Pichi-Sermoli (1948) and species diversity index was determined by the following formulae of Simpson index.

$\mathrm{D}=\mathrm{N}(\mathrm{N}-1) / \sum \mathrm{n}(\mathrm{n}-1)$

$\mathrm{D}=$ Diversity index

$\mathrm{N}=$ Total number of plants of a species

$\mathrm{n}=$ number of individuals

$\Sigma=$ Sum of all individuals of a species.

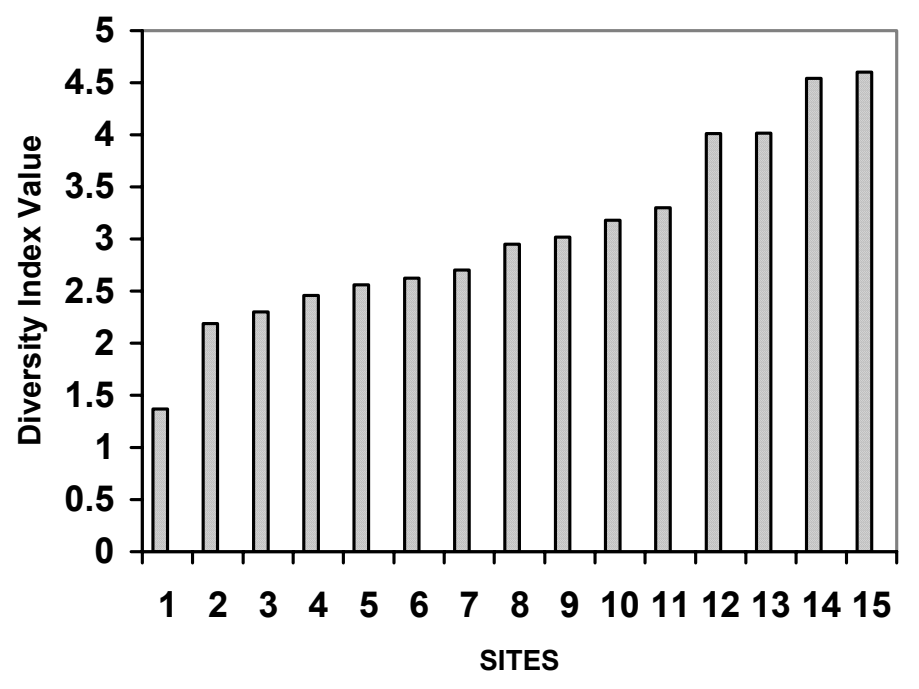

Fig. 1. Species diversity index

SAMPLING SITE: 1=Near hawksbay; 2= Manora; 3=Karachi University Stop; 4=Saeedabad Baldia Town;5= Peoples's ground; $6=$ ManoraGraved;7= Malir river at Korangi crossing; 8= Malir river around Malir river;9= Mikolachi Road;10= Korangi No.5 Shahra -eUloom;11= Mikolachi road;12= Hawksbay;13= Gaboput Kamri; 14= Bahraria complex II;15=March Morr 


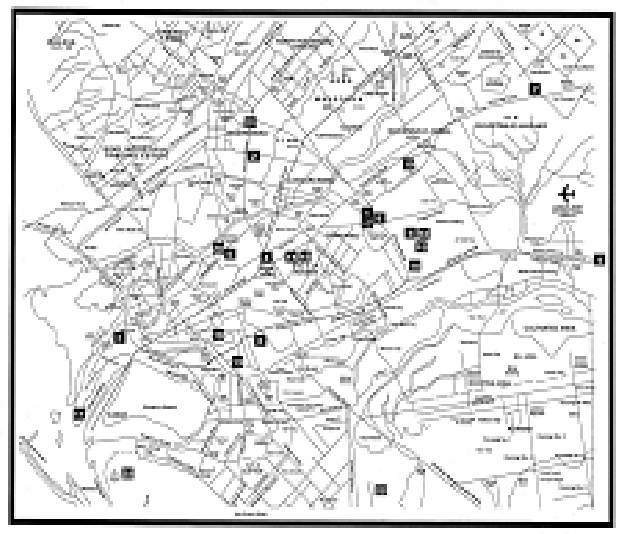

Fig 1. MAP OF THE SAMPLING SITE: $1=$ Near hawksbay; $2=$ Manora; 3=Karachi University Stop; 4=Saeedabad Baldia Town; $5=$ Peoples's ground; $6=$ ManoraGraved; $7=$ Malir river at Korangi crossing; $8=$ Malir river around Malir river;9= Mikolachi Road; $10=$ Korangi No.5 Shahra -e- Uloom;11= Mikolachi road;12 $=$ Hawksbay;13 $=$ Gaboput Kamri; 14= Bahraria complex II;15=March Morr

\section{C: Soil analysis}

One composite soil sample from each stand was also taken with the help of soil corer. The samples were brought to the laboratory in polythene bags for physical and chemical analysis. Soil texture was determined by manual as well as mechanical (sieving) methods. Soil structure was observed by hand lens observatory methods. Maximum water holding capacity (M.W.H.C.) of the soil was calculated by the following formulae. M.W.H.C. $(\%)=$ Loss in weight/oven dried weight of soil $\mathrm{X}$ 100.

The soil $\mathrm{pH}$ was determined by direct $\mathrm{pH}$ reading meter (Model JENWAY PHM 6). Calcium carbonate was determined by acid neutralization method (Qadir et al., 1961). Electrical conductivity (E.C.) of the soil samples was determined by digital conductivity meter (Beckman's conductivity meter). Sodium contents of the soil were determined by silver titration method (U.S.D.A., 1951).

\section{RESULTS}

The vegetation of studied areas showed the presence of halophytes, xerophytes and disturbed type of vegetation. A summary of phytosociological data is summarized in (Table 1). Among all the listed thirty nine plant species, Prosopis juliflora was found leading dominant in most of the stands. The stands dominated by Prosopis, formed an association with halophytes (H. recurvum, T. indica, C. cretica) and xerophyte (C. procera, S. oleoides, F. indica, P. aceolata) species. Avicennia marina as a leading dominant formed an association with halophytes (C. cretica, S. baryosma. S. fruticosa) and showed complete absence of disturbed species ( $P$. juliflora, $A$. javanica, $S$. holoseracea, A. indicum, F. indica, $S$. ovata). Whereas, Abutilon and Calotropis procera as a leading dominant showed complete absence of

* Corresponding author: Muhammad Zafar Iqbal other halophytes. Salvadora formed an association with disturbed species $P$. juliflora, and halophyte $S$. fruticosa. The stands, dominated by Limonium stocksii showed an association with both disturbed (P. juliflora) and grass species (Aleuropus). The stand dominated by Gynandropsis did not form any association with halophytes and formed an association with disturbed ( $P$. juliflora) and xerophytic species (T. terristris).

Homogeneity of Communities: The frequency distribution of all communities showed heterogeneous types of vegetation, which is in accordance with the Raunkiers law of frequency. Absence of certain classes in frequency distribution of all communities makes heterogeneous types of vegetation.

Community Maturity Index (C.M.I.): This index is an important indicator for the maturity of the communities (Table 2). Most of the plant communities showed less than 50\% CMI values. However, Prosopis in association with Pasplidium and Cenchrus community showed highest CMI value (70.00). Similarly, Prosopis in association with Suaeda and Tamarix community showed higher CMI value (56.25). Prosopis in association with Calotropis and Cenchrus showed less than (50.00) CMI value which proved the immaturity of vegetation (Table 3). Avicinnea community had lowest CMI values (10.00). Ipomea and Avicinnea in association with Cressa-Salsola had better CMI 45.83 and 40.00 values, respectively. Gynandropis, Limonium and Salvadora had CMI less than 40. A better CMI value 32.11 and 26.25 was found in Calotropis and Abutilon community.

Species diversity: The species diversity index (Simpson's index) is another important value for the community studies. Higher species diversity value is a characteristic of stable communities. The species diversity of the studied communities was generally low and ranged from 1.36 to 4.54 (Fig. 1). The highest species diversity (4.54) was observed in Prosopis community. The Avicenea and Ipomea $s p$ community had better species diversity (4.01) while, the lowest species diversity (1.36) was observed in Gynandropsis community. 
Table 1: Phytosociological summary of the community attributes

\begin{tabular}{|c|c|c|c|c|c|c|c|c|c|}
\hline Sp. No & Species name & $\begin{array}{l}\text { No of } \\
\text { times sp. } \\
\text { occurred } \\
\text { in stand }\end{array}$ & \multicolumn{4}{|c|}{$\begin{array}{l}\text { Importance Value Index } \\
\text { (I.V.I.) }\end{array}$} & \multicolumn{3}{|c|}{$\begin{array}{l}\text { No of stands } \\
\text { dominant }\end{array}$} \\
\hline 1. & Prosopis juliflora Swartz & 12 & 1280 & 107 & 198 & 27 & 6 & 3 & 1 \\
\hline 2. & Avicennia marina & 2 & 335 & 167 & 208 & 127 & 2 & - & - \\
\hline 5. & Salvadora persica $\mathrm{L}$. & 2 & 153 & 76 & 144 & 9 & 1 & - & 1 \\
\hline 6. & Cenchrus barbatus Schum & 4 & 131 & 33 & 84 & 8 & - & - & 2 \\
\hline 7. & Ipomoea sindica (Stocks) Stapf & 2 & 129 & 64 & 121 & 8 & 1 & - & - \\
\hline 8. & Halopyrum mucronatum (L.) Stapf & 1 & 106 & 106 & 106 & 106 & 1 & 1 & 1 \\
\hline 9 & Convolvululs glomerates Choisy & 3 & 104 & 34 & 80 & 80 & - & 1 & 1 \\
\hline 14. & Calotropis procera (Willd.) R.Br. & 3 & 76 & 25 & 37 & 4 & 1 & 1 & - \\
\hline 15. & Heliotropium subulatum (D.C.) Vatke & 2 & 72 & 36 & 58 & 13 & - & - & - \\
\hline 16. & Cenchrus biflorus Roxb. & 2 & 56 & 28 & 41 & 15 & - & & - \\
\hline 17. & Pasppalidium geminatum (Forsk) Stapf & 1 & 54 & 54 & 54 & 54 & - & 1 & - \\
\hline 18. & Tribulus terristris $\mathrm{L}$. & 1 & 51 & 51 & 51 & 51 & - & 1 & - \\
\hline 19. & Aeluropus macrostachyus Hack. & 2 & 50 & 25 & 36 & 14 & - & - & 1 \\
\hline 20. & $\begin{array}{l}\text { Zizyphus numularia (Buurn. f.) Wight \& } \\
\text { Arn. }\end{array}$ & 3 & 38 & 13 & 21 & 9 & - & - & - \\
\hline 21. & Aeluropus lagopoides (L) Trin.ex. Thw & 1 & 37 & 37 & 37 & 37 & - & - & - \\
\hline 22. & Fagonia indica (L.) & 2 & 35 & 17 & 19 & 6 & - & 1 & - \\
\hline 23. & Sida ovata Forrsk. & 1 & 35 & 35 & 35 & 35 & - & - & 1 \\
\hline 24. & Urochondra setulosa (Trin.) C.E. Hubb & 1 & 25 & 25 & 25 & 25 & - & - & - \\
\hline 33. & Aerva javanica (Burm. f.) Merrill & 1 & 32 & 32 & 32 & 32 & - & 1 & 1 \\
\hline 34. & Parkinsonia aculeate L. & 1 & 75 & 75 & 75 & 75 & - & 1 & - \\
\hline 35. & Heliotropium curassavicum $\mathrm{L}$. & 1 & 9 & 9 & 9 & 9 & - & - & - \\
\hline 36. & Sporobolus marginatus non Hoehst & 1 & 9 & 9 & 9 & 9 & - & - & - \\
\hline 37. & Acacia nilotica (Linn.) Delile & 1 & 8 & 8 & 8 & 8 & - & - & - \\
\hline 38. & Capparis decidua (Forssk.) Edgew. & 1 & 6 & 6 & 6 & 6 & - & - & - \\
\hline 39. & Tamarix indica Willd. & 1 & 6 & 6 & 6 & 6 & - & - & 1 \\
\hline
\end{tabular}

The disturbance: The disturbances were of various type and degree on the study sites (Table 2). One thing was common that the disturbance was a mean to reduce species diversity and to reduce plant growth. The phenology of the plants on disturbed areas was not good although they had received a good shower in the monsoon season couple of months back.

Soil Characteristics: The soil of the study area was alkaline in nature with loamy sand, sandy loam, loamy silt and silty having a considerable amount of calcium carbonate, which is a characteristic feature for arid soil. Eight stands were found on loamy sand and three on loamy silt while two on silty and two on sandy loam (Table
3). Fifteen plant communities were identified. Propsopis community formed six different types of association (Prosopis-Paspilidium-Cenchrus, Prosopis-Calotropis-Salvadora, $\quad$ ProsopisCenchrus-Cressa, Prosopis-suaedea-Tamarix, Prosopis-Parkinsonia-Halopyrum and ProsopisFagonia-Cenchrus) times leading first dominant species. Similarly, Avicenia community formed two types of community as Avicenia-CressaSuaeda and Avicenia-Cressa-Salsola respectively. Therefore, these communities were explored as (Prosopis, Avicennia, Gynandropsis, Salvadora, Ipomea, Halopyrum, Limonium, Abutilon, and Calotropis) community and their edaphic characters are explained as follows: 
Table2: Community Maturity Index (C.M.I.), study site, nature of disturbance and total number of species in stand

\begin{tabular}{|c|c|c|c|c|c|}
\hline $\begin{array}{l}\text { Stand } \\
\text { No. }\end{array}$ & Plant Community & Study site & Disturbance & CMI & $\begin{array}{l}\text { Total No } \\
\text { of species } \\
\text { in stands }\end{array}$ \\
\hline 1 & Halopyrum-Convolvolus-Suaeda & Manora Graved & Naval activities & 50 & 8 \\
\hline 2 & Avicenia-Cressa-Suaeda & Manora & Construction of road & 10 & 6 \\
\hline 3 & Ipomea-Halopyrum-Convolvolus & Gaboput Kamri & Salinity, polluted sea water & 46 & 6 \\
\hline 4 & Gynandropsis-Tribulus-Prosopis & Near hawksbay & Salinity & 31 & 5 \\
\hline 5 & Limonium-Prosopis-Aleuropus & Hawksbay & Salinity & 38 & 8 \\
\hline 6 & Prosopis-Paspalidium-Cenchurs & $\begin{array}{l}\text { Malir river around } \\
\text { Malir river }\end{array}$ & Water, air pollution & 70 & 4 \\
\hline 7 & Avicenia-Cressa-Salsola & $\begin{array}{l}\text { Malir river at Korangi } \\
\text { crossing }\end{array}$ & $\begin{array}{l}\text { Traffic, air and water } \\
\text { pollution }\end{array}$ & 40 & 8 \\
\hline 8 & Salvadora-Prosopis-Suaeda & Mikolachi road & Tasman strip & 38 & 6 \\
\hline 9 & Prosopis-Calotropis-Salvadora & March Morr & Lyari express way & 39 & 6 \\
\hline 10 & Prosopis-Cenchrus-Cressa & Peoples's ground & $\begin{array}{l}\text { Traffic, air and dust } \\
\text { pollution }\end{array}$ & 35 & 6 \\
\hline 11 & Prosopis-Suaeda-Tamarix & Mikolachi Road & Tasman strip spill & 56 & 4 \\
\hline 12 & Prosopis-Parkinsonia-Haloxylon & Bahraria complex II & Construction & 35 & 7 \\
\hline 13 & Prosopis-Fagonia-Cenchrus & Saeedabad Baldia Town & Houses,road construction & 20 & 9 \\
\hline 14 & Calotropis-Aerva-Senna & Karachi University Stop & Plaza construction & 32 & 7 \\
\hline 15 & Abutilon-Prosopis-Sida & $\begin{array}{l}\text { Korangi No.5 Shahra } \\
\text {-e- Uloom }\end{array}$ & Grazing, polluted water & 26 & 8 \\
\hline
\end{tabular}

Table 3. Soil characteristics of different disturbed habitats

\begin{tabular}{|c|c|c|c|c|c|c|c|c|c|c|}
\hline \multirow[t]{2}{*}{ Plant community } & \multicolumn{10}{|c|}{ Soil Characteristics } \\
\hline & $\begin{array}{l}\text { Soil } \\
\text { texture }\end{array}$ & $\begin{array}{l}\text { Soil } \\
\text { structure }\end{array}$ & $\begin{array}{l}\text { Sand } \\
\%\end{array}$ & $\begin{array}{l}\text { Silt } \\
\%\end{array}$ & $\begin{array}{l}\text { Clay } \\
\%\end{array}$ & $\begin{array}{l}\text { MWHC } \\
\%\end{array}$ & $\mathrm{pH}$ & $\begin{array}{l}\mathrm{CaCO}_{3} \\
\%\end{array}$ & $\begin{array}{l}\mathrm{EC} \\
\mu \mathrm{s} / \mathrm{cm}\end{array}$ & $\begin{array}{l}\mathrm{Na} \\
\mathrm{ppm}\end{array}$ \\
\hline $\begin{array}{l}\text { Halopyrum-Convolvolus- } \\
\text { Suaeda }\end{array}$ & SL-LS & $\mathrm{RP}$ & 81 & 12 & 4 & 23 & 7.54 & 13 & 242 & 146 \\
\hline Avicenia-Cressa-Suaeda & LS-SL & RP & 84 & 10 & 5 & 19 & 7.56 & 21 & 473 & 285 \\
\hline $\begin{array}{l}\text { Ipomea-Halopyrum- } \\
\text { Convolvolus }\end{array}$ & SL-LS & $\mathrm{RP}$ & 82 & 11 & 4 & 22 & 7.53 & 13 & 242 & 145 \\
\hline $\begin{array}{l}\text { Gynandropsis-Tribulus- } \\
\text { Prosopis }\end{array}$ & LST & RNP & 17 & 58 & 24 & 41 & 7.85 & 26 & 593 & 357 \\
\hline Limonium-Prosopis-Aleuropus & LST & RNP & 9 & 57 & 31 & 45 & 7.85 & 26 & 593 & 357 \\
\hline $\begin{array}{l}\text { Prosopis-Paspalidium- } \\
\text { Cenchurs }\end{array}$ & LST & RNP & 5 & 58 & 37 & 48 & 7.85 & 23 & 590 & 355 \\
\hline Avicenia-Cressa-Salsola & ST & RNP & 4 & 90 & 5 & 40 & 7.86 & 21 & 473 & 285 \\
\hline Salvadora-Prosopis-Suaeda & ST & RNP & 5 & 88 & 6 & 39 & 7.85 & 22 & 593 & 357 \\
\hline Prosopis-Calotropis-Salvadora & LS, S & $\mathrm{AB}$ & 87 & 8 & 4 & 19 & 7.20 & 14 & 242 & 145 \\
\hline Prosopis-Cenchrus-Cressa & LS, S & $\mathrm{AB}$ & 87 & 8 & 4 & 19 & 7.10 & 14 & 241 & 145 \\
\hline Prosopis-Suaeda-Tamarix & LS, S & $\mathrm{RP}$ & 85 & 10 & 4 & 19 & 7.85 & 26 & 593 & 357 \\
\hline $\begin{array}{l}\text { Prosopis-Parkinsonia- } \\
\text { Haloxylon }\end{array}$ & LS, S & $\mathrm{RP}$ & 87 & 8 & 4 & 19 & 7.35 & 26 & 593 & 357 \\
\hline Prosopis-Fagonia-Cenchrus & LS, S & $\mathrm{RP}$ & 87 & 8 & 4 & 19 & 7.45 & 16 & 323 & 195 \\
\hline Calotropis-Aerva-Senna & LS & RAB & 83 & 13 & 5 & 19 & 7.42 & 16 & 399 & 240 \\
\hline $\begin{array}{l}\text { Abutilon-Prosopis-Sida } \\
\text { Symbol Used: }\end{array}$ & LS-S & RAB & 87 & 8 & 4 & 19 & 7.45 & 16 & 333 & 201 \\
\hline
\end{tabular}

Prosopis community: Prosopis community formed six different types of association with halophytic and xerophytic species such as $H$. recurvum, $C$. cretica, S. fruticosa and T. indica. The soil characteristics of Prosopis community showed variation in the nutritional value of soil characteristics. This community in association with C. procera, S. persica, C. barbata, C. cretica, S. fruticosa, T. indica, P. aceolata, H. mucronatum and $F$. indica preferred to grow on high percentage of sand (85-87\%) and low amount of silt (8-10\%) and clay $(4 \%)$ particles. The community had low percentage of maximum water holding capacity (19\%). Whereas, Prosopis community in association with $P$. gyminatum and $C$. setigerus preferred to grow on highest percentage of silt (58\%) and Maximum Water Holding Capacity (48\%). The soil of the community had better calcium carbonate $(23 \%)$ with alkaline soil $\mathrm{pH}$ (7.10-7.85). The concentrations of sodium content were found in the range of 145-357 ppm. The community preferred electrical conductivity (EC) in the range of $241-593 \mu \mathrm{s} / \mathrm{cm}$. 
Avicenia community: This community is dominated by halophytes. The community formed an association with other halophytes $C$. cretica, $S$. fruticosa and $C$. certica. The community in association with $C$. cretica and $S$. fruticosa preferred to grow on high percentage of total sand $(84 \%)$ along with better percentage of silt $(10 \%)$, clay particles (5\%) and low MWHC (19\%). This community prefers to grow on sandy loam to loamy sand soil type. The soil of the community had slightly alkaline $\mathrm{pH}$ (7.56) with high sodium content $(285 \mathrm{ppm})$ and electrical conductivity (473 $\mu \mathrm{s} / \mathrm{cm})$. While the same community in association with $C$. cretica and $S$. baryosma preferred to grow on highest percentage of silt $(90 \%)$ along with low percentage of silt $(4 \%)$, clay particles $(5 \%)$. The community prefers to grow on better MWHC $(40 \%)$. The soil of the community had highest alkaline $\mathrm{pH}$ (7.86).

Gynandropsis community: Gynandropsis formed an association with $T$. terristris and disturbed species, $P$. juliflora. This community prefers to grow on loamy silt soil type. The community had better percentage of total sand $(17 \%)$, silt $(58 \%)$ and clay particles $(24 \%)$. The maximum water holding capacity of the soil was $41 \%$ and soil was loamy silt. The soil $\mathrm{pH}$ (7.85) and $\mathrm{Na}^{+}$(357 ppm) contents were moderate in the community. The dominance of the community might be due to the highest EC $(593 \mu \mathrm{s} / \mathrm{cm}), \mathrm{EC}(0.59 \mathrm{ds} / \mathrm{m}$ and calcium carbonate $(26 \%)$.

Salvadora community: $S$. persica formed an association with both disturbed species, $P$. juliflora and halophytes $S$. fruticosa. It appeared to grow at the low percentage of total sand $(5 \%)$, clay $(6 \%)$, high percentage of silt $(88 \%)$ and better water holding capacity $(39 \%)$. This community prefers to grow on silty types of soil. The community was found to grow on high percentage of calcium carbonate $(22 \%)$ as compared to other plant communities. The community had slightly alkaline soil $\mathrm{pH}(7.85), \mathrm{EC} 593 \mu \mathrm{s} / \mathrm{cm}$ and sodium level, and $357 \mathrm{ppm}$.

Ipomea community: Ipomea community formed main association with halophytes (H. mucronatum) and creeping $C$. conglomerates. The soil of the community had a high percentage of total sand $(82 \%)$ with better percentage of silt $(11 \%)$ and clay (4\%) particles. The soil was sandy loam and loamy sand with slightly alkaline $\mathrm{pH}$ (7.53). The community showed moderate concentration of calcium carbonate $(13 \%), \mathrm{Na}^{+}$salt $(242 \mathrm{ppm})$ and EC $242 \mu \mathrm{s} / \mathrm{cm}$, respectively.

Halopyrum community: Halopyrum community formed main association with halophytes $S$. fruticosa and creeping plant species $C$. conglomerates. The community was found on soil having high percentage of total sand $(81 \%)$ with

\footnotetext{
* Corresponding author: Muhammad Zafar Iqbal
}

lowest percentage of clay particles (4\%). However, the amount of silt was moderate $(12 \%)$. This community prefers to grow on sandy loam to loamy sand. The community prefers to grow on better water holding capacity of soil $(23 \%)$. Lowest percentage of calcium carbonate $(13 \%)$ was observed in this community. Other soil characteristics of community such as $\mathrm{EC}, \mathrm{Na}, \mathrm{K}$ and $\mathrm{pH}$ were low.

Limonium community: Limonium community formed main association with disturbed species $P$. juliflora and grass $A$. lagopoides. Species $C$. conglomerates. The community was found on soil having low percentage of total sand $(9 \%)$ with high percentage of clay particles $(31 \%)$. However, the amount of silt was moderate $(57 \%)$. However, the water holding capacity of community soil was moderate $(45 \%)$. This community prefers to grow on loamy silt soil type. The community had high calcium carbonate (26\%). The other soil characteristics such as $\mathrm{pH}(7.85)$, EC $(593 \mu \mathrm{s} / \mathrm{cm})$ and $\mathrm{Na}$ (357 ppm) were high.

Abutilon community: Abutilon community formed main association with disturbed species $P$. juliflora and xerophytes $S$. ovata. The community was found on soil having high percentage of total sand $(83 \%)$ with better percentage of clay $(5 \%)$ and silt particles $(13 \%)$ and prefers to grow on sandy to loamy sand types of soil. The community had the low water holding capacity of soil (19\%) along with better amount of calcium carbonate (16\%). The other soil characteristics such as $\mathrm{pH}$ (7.42), EC $(399 \mu \mathrm{s} / \mathrm{cm})$ and $\mathrm{Na}(240 \mathrm{ppm})$ were moderate.

Calotropis community: Calotropis community formed main association with xerophytes species likewise $A$. javanica and $S$. holosericea. This community preferred to grow on loamy sand soil type. The community was found on soil having high percentage of total sand $(87 \%)$ with lowest percentage of silt and clay particles (4\%). The community had the lowest water holding capacity (19\%). The other soil characteristics such as $\mathrm{pH}$ (7.45), EC (333 $\mu \mathrm{s} / \mathrm{cm})$ and $\mathrm{Na}(201 \mathrm{ppm})$ were moderate.

\section{DISCUSSION}

In order to assess ecological knowledge of the native flora in southern site of Pakistan, a quantitative phytosociological study in different areas of the city was carried out. Importance value index (I.V.I.) for each plant species was determined to quantify the importance of each species. The vegetation of the studied sites is composed of halophytic, xerophytic and disturbed species. The disturbance is mainly due to the construction of roads, flyover, salinity, discharge of pollutant on soil surface without any pretreatment and animal grazing. These activities are responsible in 
converting natural vegetation to semi natural vegetation. An important component of any ecosystem is the species it contains. Species also serves as good indicators of the ecological condition of a system (Morgenthal, et al., 2001). A list of all species collected during the study was compiled. The floristic composition of different area was also compared. The species composition of the fifteen stands was considerably different. Halophytes were, for example, more abundant on the soil having high salt content in the area. Vegetation analysis gives the information necessary to determine the name of community and provide data that can be used to compare it with other communities. Nine plant communities; Prosopis, Avicennia, Suaeda, Gynandropsis, Salvadora, Ipomea, Limonium, Calotropis and Abutilon were observed as a leading dominant. The leading dominants of one stands was also found in other stands as co-dominant. The communities in the study area were heterogeneous. The absence of certain frequencies classes in the communities reflected the heterogeneity of the vegetation, which is either due to biotic disturbance or the floral poverty. The result obtained by Raunkiaer (1954) may be regarded only as possibilities to be confirmed by other alternative approaches.

The concept of species diversity relates simply to "richness" of a community or geographical area in species. At the simplest level of examination, species diversity corresponds to the number of species present. Species diversity is considered to be an important attribute of community organization and allowed comparison of the structural characteristics of the communities. It is often related to community dynamics stability, productivity, integration, evolution, structure and competition. The idea of displacement of one species through competition with other is net prime importance. The species diversity was low and the community maturity index was below $50 \%$, which indicates that the communities are under several changes except stands dominated by ProsopisPaspalidium-Cenchrus and Prosopis-SuaedaTamarix community. This might be due to occurrences of lowest number of plant species present in stand and variation in edaphic characteristics of community. Furthermore, variation in plant growth due to changes in edaphic and climatic conditions in S. fruticosa (L.) and Tamarix indica Willd from the saline community of Karachi University Campus was investigated (Maryam, et al., 1995). The halophytes besides having sand binding and salt absorption properties also have a great economic importance for use as a forage, fodder, oil crops, pulp, paper industry and fuel wood (Malcolm, 1993). High percentage of silt $(58 \%)$, clay $(37 \%)$, and maximum water holding capacity of soil (48\%) in Prosopis-PaspalidiumChencrus community might be reason of such change. The findings are similar to the investigation of Matthews, et al., (2001). In hierarchical classification, vegetation map, description and ecological interpretation of the plant communities of the Tembe Elephant Park and surrounding areas dynamics of water in the landscape either directly or indirectly, through its role in moisture levels and soil formation play a role in the determination of plant communities at the higher levels. Species richness was found to be highest in associations with high structural diversity and species turnover was strongest where environmental heterogeneity was high (Hoare and Bredenkamp, 2001). A strong dominance by $P$. juliflora is likely to continue within the both disturbed and halophyte community type. Establishment by the co-dominant, S. fruticosa suggests an increasing importance of this species. However, $P$. juliflora in association with $F$. indica and $C$. procera appears to be particularly adapted to the xeric condition of soil Similar types of vegetation around the Lyari river was found and mostly dominated by monocotyledonous species viz Paspalidium geminatum, Cyperus laevigatus, Chloris barbata and Aeluropus lagopoide. (Iqbal et al., 1998). P. geminatum was the most common and widely distributed species along the waste effluent in the study areas. Plant growth and development are the result of many physiological processes, which are influenced by soil moisture (Mondal and Paul, 1992; Begum and Paul, 1993). Distribution of plant communities mostly depends upon the edaphic factors, like, soil texture, structure, $\mathrm{pH}$, moisture and mineral composition. Soil salinity alone of in combination with water logging play an important role in distribution of halophytes. Variation in total salinity, depth of soil horizon and extent of water logging can greatly influence the vegetation of an area including halophytes (Maryam, et al.,1995). Prosopis community preferred to grow on wide range of water holding capacity of soil $19-48 \%$, resulting in the formation of six different types of plant association.

Differences in rehabilitation treatment, age of rehabilitation and man-made disturbances were observed in some of the important factors determining the establishment of different communities, such as on ash disposal sites. Statistically significant differences were found in the diversity of vegetation on a community and variant level (Morgentha, et al.,2001). One of the main factors influencing plant distribution is the type of soil. Most plants are specially adapted to more or less specific soil types. The distribution and composition of plant communities is there's seems to be affected by climatic and underlying edaphic factors. The soil of the study area was alkaline in nature with sandy loam, loamy sand, loamy silt, sandy and silty. An appreciable amount of calcium carbonate is a common feature of arid area soil. Soil of the communities showed significant variation in their characteristics. However, some communities recognized in the 
study area are also found in other parts of the country. The construction of flyover, roads, salinity, indiscriminate discharge of pollutant, dumping of soil waste and increasing human activities disturbing the natural vegetation pattern of the study areas. Similar conclusion was drawn by Akbar and Ahmed (1991) about the vegetation of Quaid-e-Azam University campus. Out of 39 species, eighteen species were occurred as a first, second or third dominant in community. Maximum numbers of species (9) were found in ProsopisFagonia-Cenchrus community. The number of species per site varied with the species dominating the site and the soil characteristics of the site. Halophytic communities were composed of lesser number of species as compared to glycophytes communities (Khan and Shaukat, 2005). The natural vegetation of all the three sites in the reserve areas of Natural Park Lalsuhanra was mainly herbaceous but in degrading form. Because of overgrazing, the vegetation cover in unfenced desert areas was in decreasing state as compared to protected area (Arshad, et al., 2002). Reduction in number of species was noted in few stands due to pollution area as compared to other areas. The presence of $P$. geminatum as a co dominant population suggested that this species has tolerance to pollution condition. In physiological mechanism of pollution injury, many factors such as light, wind, water, temperature and mineral nutrient affects the responses of plants to pollutant. The soil characteristics along water channels showed a significant correlation with vegetation type. $P$. Juliflora had wide ecological amplitude and was found as a first dominant in different stand with a range (7.10-7.85) of soil $\mathrm{pH}$. A change in $\mathrm{pH}$ values caused changed in association between species. (Iqbal, et al., 1998).

Calcium carbonate is widely distributed in soil occurring separately or they may be associated with other salts. Hawksbay area soil has better concentration of calcium carbonate. High percentage of calcium carbonate made the biological activity high, which make the soil fertile. A variation in calcium carbonate concentration had also showed relationships with vegetation types. $G$. Gynandra formed a dominant community at the highest concentration of $\mathrm{CaCO}_{3}$. The amount of exchangeable sodium was found in appreciable concentration, as in arid area. Where precipitation is insufficient to leach out the soluble sodium salts. A variation of concentration of sodium salts had a marked influenced on vegetation. At lowest concentration of sodium $146 \mathrm{ppm}$, Halopyrum community preferred to grow in association with $C$. glomeratus and $S$. fruticosa. Halopyrum community preferred to grow on better edaphic variable $\left(\mathrm{pH} 7.45, \mathrm{CaCO}_{3} 16 \%\right.$, and sodium salt $201 \mathrm{ppm}$ ) helped in the formation of xerophytic and disturbed types of vegetation.

The ecology of different plant communities from different sites of Karachi, showed variation in nature, structure, composition of vegetation and soil characteristic. Most of the species were halophytes, xerophytes and in disturbed nature. The majority of individuals of plant population were seen in danger. Various types of activities have modified the plant cover over wide areas. There is a need to develop plant-protected areas. Cultivation of wild species and grasses will help in soil binding and maintaining the richness of the nutrient cycle of the soil. Scientific information relating to the composition of vegetation can be helpful for proper rehabilitation of the affected area because this forms the basic element for the conservation of important and endangered flora and fauna of any region. Protection of the natural flora from over grazing is necessary, especially during the time when the desirable plants set their seeds. Protection is essential to maintain the desirable forage plant species in a good proportion, to avoid invader plant species and to rehabilitate the destroyed natural flora (Arshad, et al., 2002). We must carry out our efforts to make a list of the plant species, which can be lost from the natural environment, otherwise it will leads to desertification. Desertification associated with human activities has been recognized over the past 2 decades as one of the important facets of ongoing global environmental change (Verstraete and Schwartz, 1991; UNEP, 1997; Huenneke, et al., 2002) and Species loss can alter the goods and services provided by ecosystems (Hooper, et al., 2005).

Community structure, on a variant level, is largely determined by different treatments (seed mixtures and soil preparations) that were used in the rehabilitation of the ash disposal sites. Periodical survey on natural plant communities by comparing with plant communities of rehabilitated sites, on dumps of domestic refuse, industrial refuses carried out. The reconstruction of plant communities on disturbed sites with a species composition similar to that of the natural area will require allocation of more financial inputs. The saving and establishment of plant communities one of the major tasks facing by ecologist. Extensive work on the development of vegetation depends upon good indigenous vegetation recovery. Preservation of these communities especially within disturbed sites is more generally, demands a unique and pressing conservation challenge. Extinction of some rare species would result in the increase of the prevalence of relatively stable species, such as $P$. juliflora. It is concluded that salinity, discharge of different types of pollutant and various types of are adversely affecting the nature, structure and composition of plant communities. Construction of buildings and roads in the area is additional source of disturbance. It is suggested that the discharge of untreated polluted water must be checked. Plantation near the construction of new structure and roads should be increased. Plant material and soil analysis should be carried out periodically, to monitor the toxic levels of pollutant. Periodical 
ecological survey, knowledge of vegetation and their relationship with soil characteristic can be helpful for future development project like botanical garden. Plant ecological surveys of all the disturbed and threatened areas on permanent basis are required to know their current biodiversity situation and future continuity status. Plantation of indigenous plants in the city is necessary. Government and we must try to support the civic agencies to save the natural biodiversity of the area. There is also a need to control on the sources of disturbances and pollution causing damage to natural vegetation. Establishment of plant-protected area at the center of the city is suggested due to large-scale reduction in number of species.

\section{REFRENCES}

Ahmed, F; Burney, SMA; Hussain, SA (1991). Monthly average daily global and diffuse solar radiation and its correlation with hours of bright sunshine of Karachi, Pakistan. Renewal Envergy, 1: 115 - 118.

Ahmed, S; Khattak, ZD (2001). Quantitative studies on the vegetation of Islamabad. Pakistan Journal of Scientific and Industrial Research. 44(5): 279 - 285.

Akbar, K F; Ahmed, T (1991). Phytosociological study of the Quaid-e-Azam University campus. Pakistan Journal of Agriculture Research, 12: 264 - 273.

Arshad, M; Salahuddin; Rao, A (2002). Phytosociological Assessment of natural reserve of national park Lalsuhanra (Punjab, Pakistan). Asian Journal of Plant Sciences 1 (2): $174-175$.

Aziz, I.; Gulzar, S; Noor, M; and Khan, MA (2005). Seasonal variation in water relations of Halopyrum mucronamtum (L.) Stapf. Growing near sandspit, Karachi. Pakistan Journal of Botany, 37(1): 141 - 148.

Begum, FA; Paul, NK (1993). Influence of soil moisture on growth, water use and yield of mustard (Brassica juncea L.). Journal of Agronomy and Crop Science. 170: 136 -141.

Cottom, G; Curtis, JT (1956). The use of distance measured in phytosociological sampling. Ecology, 37: 451 - 60.

Curtis, JT; McIntosh, RP (1951). An upland forest continues in the praire forest border region of Wisconsin. Ecology, 32: 476 - 449.

Dasti, A; Agnew, ADQ (1994). The vegetation of Cholistan and Thal desert, Pakistan. Journal of Arid Environment, 27: 193 - 208.

* Corresponding author: Muhammad Zafar Iqbal
Delgadillo, J; Peinado, M; De la Cruz, M; Martinez-Parras, JM; Alcarazy F; de la Torre, A. (1992). Analisis fitosociologico de los saladares y manglares de Baja California, México. Acta Botánica Mexicana, 19: 1-35.

Hoare, DB; Bredenkamp, GJ (2001). Syntaxonomy and environmental gradients of the grasslands of the Stormberg / Drakensberg mountain region of the Eastern Cape, South Africa. South African Journal of Botany, 67 (4): 595 608 .

Hooper, DU; Chapin, FS; Ewel, JJ; Hector, A; Inchausti, P; Lavorel, S; Lawton, JH; Lodge, DM; Loreau, M; Naeem, S; Schmid, B; Setälä, H; Symstad, AJ; Vandermeer, J; Wardle, DA. (2005). Effects of biodiversity on ecosystem functioning: a consensus of current knowledge, Ecol. Monogr. 75: 3-35.

Huenneke, LF.; Anderson, JP.; Remmenga, M.; Schlesinger, WH. (2002). Desertification alters patterns of aboveground net primary production in Chihuahua ecosystems, Global Change Biology 8: 247-264.

Iqbal, MZ; Hussain, SMA (1994). Estimating future trend of vegetation in Karachi. Karachi University Journal Science, 22(1-2): 127 - 133.

Iqbal, MZ (1998). Soil plant community relationships in disturbed areas in the vicinity of Karachi, Pakistan. Sindh University Research Journal (Sci. Sr). 30 (1): 7-9.

Iqbal, MZ; Gill, D; Shafiq, M (1998). Plant communities along the sewage effluents channels of Lyari river in Pakistan. Taiwania, 43(1): 1 - 11 .

Iqbal, MZ; Maleeha, S; Shafiq, M (2002). Plant and soil relationship in different halophytic communities. Prospects for Saline Agriculture in (Editors R. Ahmad and K.A. Malik). Pp. 377-383, Kluwer Academic Publishers, Netherlands.

Iqbal, MZ; Sherwani, AK; and Shafiq, M (1999). Vegetation characteristics and trace metals $(\mathrm{Cu}, \mathrm{Zn}$ and $\mathrm{Pb})$ in soils along the super highways near Karachi, Pakistan, Studia Botanica Hungarica, 29: 79 - 86.

Khan, A (1993). Relationship of seed bank to plant distribution in saline arid communities. Pakistan Journal of Botany, 25: 73 - 82.

Khan, MA; Ungar, IA; Showalter, AM (1999). Effects of salinity on growth, ion content and osmotic relations in Halopyrum mucrantum 
(L.) Stapf. Journal of Plant Nutrition, 22: 191 $-204$.

Khan, D; Shaukat, SS (2005). Above ground standing phytomass of some grass dominated communities of Karachi: Winter aspect. International Journal of Biology and Biotechnology, 2(1): 85 - 92.

Khan, D; Alam, MM; .Faheemuddin, M (1999). Structure, composition and above ground standing phytomass of some grass dominated communities of Karachi. Summer Aspect. Hamdard Meduicus, XLII: 19 - 52.

Lehsten, V: Kleyer, M. (2007). Turnover of plant trait hierarchies in simulated community assembly in response to fertility and disturbance. Ecolgical Modelling, 203 (3-4): 270-278.

Maryam, H; Ismail, S; Ali, F; Ahmad, R (1995). Studies on growth and salt regulation in some halophytes as influenced by edaphic and climatic conditions. Pakistan Journal of Botany, 27(1): 151 - 163.

Matthews, WS; Wyk, AEV; Rooyen, NV; Botha, GA (2001). Vegetation of the Tembe Elephant Park, Maputaland, South Africa. South African Journal of Botany 67 (4): 573 - 594.

Morgentha, TL; Cilliers, SS; Kellner, K; Hamburg, HV; Michael, MD (2001). The vegetation of ash disposal sites at Hendrina power station I: Phytosociology. South African Journal of Botany 67 (4): 506 - 519.
Morgenthal, TL; Cilliers, SS; Kellner, K; Hamburg, H.V; Michael, MD (2001). The vegetation of ash disposal sites at Hendrina Power Station II: Floristic composition South African Journal of Botany 67 (4): 520 - 532.

Pichi-Sermoli, R (1948). An index for establishing the degree of maturity in plant communities. Journal of Ecology, 36: 85 - 90.

Qadir, SA; Qureshi, SZ; Ahmed, MA (1966). A phytosociological survey of Karachi University Campus. Vegetatio, 20: 339 - 362.

Raunkiaer, C (1934). The life forms of plants and statistical. Plant Geography, Being the collected papers of C. Raunkiaer. Oxford, Clarendon Press. 632 pp.

Shafiq, M.; Iqbal, MZ; Habib, I (1992). Phytosociological studies around the industrial areas of Landhi, Karachi. New Agriculturist, 3(2): 179-188.

United Nations Environment Program (UNEP) (1997). World Atlas of Desertification. 2nd ed. Edward Arnold, London, and Wiley, New York, USA.

U.S.D.A. (1951). Soil survey manual Handbook No. 18. U.S. Department of Agriculture, U.S. Government Printing Office, Washington, D.C.

Verstraete, M.M.; Schwartz, S.A. (1991). Desertification and global change, Vegetatio 91: 3-13. 